\title{
4
}

\section{The Three Ages of Utmost Good Faith}

\author{
HOWARD BENNETT
}

\section{Introduction}

It is axiomatic that insurance contracts have a different underlying ethos from other contracts, a difference that is conveniently and pithily encapsulated by the concept of 'utmost good faith'. General contract law does not advocate bad faith, but insurance contract law has higher expectations. The prime manifestation of these expectations lies in the rules that attach to contract negotiation. General contract law requires statements made to be true but affords each negotiating party a largely free choice as to whether to make any statements. ${ }^{1}$ Insurance contract law imposes a duty to speak and equates silence with a false statement. The resulting duty of disclosure has understandably attracted considerable attention given the onerous nature of the obligation imposed on the assured and, historically at least, the strictness of the remedies for breach. Until relatively recently, however, comparatively little focus was placed on an underlying, pervasive idea or doctrine of utmost good faith. This chapter is concerned with utmost good faith in that broader sense.

The chapter considers utmost good faith from a chronological perspective, distinguishing three ages in its evolution. The first age extends from the earliest reference in insurance contract law to utmost good faith throughout an initial period during which its impact was untrammelled by any statutory intervention. The second age is the period of nearly 110 years during which utmost good faith was, in part at least, the subject of sections 17-20 of the Marine Insurance Act 1906 as originally drafted. The 1906 Act transformed utmost good faith from a pervasive, underlying ethos into a formal legal doctrine. Particular problems were generated by the attachment to section 17's articulation of utmost good faith as the basis of marine insurance contracts of a specific remedy for non-observance, namely avoidance of the contract. The third age was ushered in by the Insurance Act 2015, which repealed most of the relevant provisions of the 1906 Act while amending section 17 so as to remove any reference to remedies. A central theme of this chapter is that utmost good faith affects insurance contracts in a diversity of ways that require remedial flexibility. This imperative drives a proper understanding of utmost good faith in its second age. The welcome removal by the 2015 Act of the section 17 remedial straitjacket restores to the doctrine its full creative potential. Nevertheless, the extent to which insurance contract

\footnotetext{
${ }^{1}$ One exception is the rule in Smith $v$ Hughes (1870-71) LR 6 QB 597 (QB) against taking advantage of known mistakes by the other party as to the terms of the contract.
} 
law truly needs an idea or doctrine of utmost good faith is questionable. Various principles that have developed under the auspices of utmost good faith, or at least with the support of insurance contracts being characterised by utmost good faith, could have evolved at common law as independent, bespoke principles of insurance law sustained by their own merits.

\section{The First Age: The Age of Common Law}

The seminal judgment of Lord Mansfield in Carter $v$ Boehm ${ }^{2}$ provides a logical starting point for an account of the doctrine of utmost good faith in English insurance contract law. ${ }^{3}$ Lord Mansfield articulated a general principle and a systematic series of propositions concerning the non-disclosure of information in the course of contractual negotiations. The judgment enjoys a deserved enduring prominence, but there are certain claims that it cannot make.

First, Carter v Boehm is not the earliest reported English case relating to pre-formation disclosure in insurance contracts. That honour falls to De Costa $v$ Scandret ${ }^{4}$ decided in the Court of Chancery in 1723, in which the assured failed to disclose to the insurer intelligence he had received that the ship proposed for insurance was in danger of being lost. Such 'concealing' was considered a 'fraud', as disclosure would have led the insurer either to decline the risk or to require a higher premium. ${ }^{5}$ Another earlier reported case is Seaman v Fonereau ${ }^{6}$ in 1742 , in which an insurer was held entitled to reject a claim for loss by capture on the ground of nondisclosure of information that an accompanying vessel had lost contact with the insured vessel, which was leaking, and that the following day there had been a 'hard gale', the materiality of the information being determined as at the time of conclusion of the contract and it being, therefore, irrelevant that the undisclosed matter had no bearing on the casualty. Nor is Carter $v$ Boehm even Lord Mansfield's earliest reported case on non-disclosure in insurance contracts. Decided one year earlier, conjoined appeals in Salvador $v$ Hopkins and Heaton $v$ Rucker ${ }^{7}$ were two of nine cases arising out of the insurance of a vessel employed in the East India trade covering a homebound voyage from India to England and prior trading between Indian ports. The underwriters' allegation of non-disclosure of the assured's expectations as to the extent of such prior trading was rejected on the basis that the customary trading practices within the East India trade were sufficiently notorious and well known to the insurers as to fall within their deemed knowledge. It was in Carter v Boehm, however, that Lord Mansfield articulated, for the first time, a coherent set of principles for English law.

Secondly, neither Carter $v$ Boehm nor the earlier cases just mentioned constitute the origin of the assured's pre-formation disclosure obligations in English law. The London marine insurance customs drawn up at the instigation of the Privy Council in the 1570s in A Booke of Orders of Assurances within the Royall Exchange (also known as the London Code) provided that the

\footnotetext{
${ }^{2}$ Carter v Boehm (1766) 3 Burr 1905, 97 ER 1162.

${ }^{3}$ eg the leading monograph, P MacDonald Eggers and S Picken, Good Faith and Insurance Contracts, 4th edn (London, Informa Law, 2017) para 1.01.

${ }^{4}$ De Costa v Scandret (1723) 2 P Wms 170, 24 ER 686.

${ }^{5}$ The same point apparently arose the following term in a second, unreported, case called Weaver $v$ Fowler: M Postlethwayt, The Universal Dictionary of Trade and Commerce, 4th edn (London, W Strahan and others, 1774) vol 1, sv 'Assurance' and 'Remarks'.

${ }^{6}$ Seaman $v$ Fonereau (1742) 2 Str 1183, 93 ER 1115.

${ }^{7}$ Salvador v Hopkins (1765) 3 Burr 1707, 97 ER 1057.
} 
assured 'shall not conceale any thing, that may tend to the hurt and hindrance of the Assurer, but with playne and true meaning shall give and continue his Assurreance. ${ }^{8}$ This provision, it has been suggested, was derived from Dutch insurance legislation of $1571,{ }^{9}$ although the assured's obligation under that legislation was confined to stating in the policy certain specified information. ${ }^{10}$

Thirdly, Carter v Boehm is not the origin of the idea that an enhanced concept of good faith applies to insurance contracts, and therefore not the origin of the application to insurance contracts of a turn of phrase so indicating. As is well known, Lord Mansfield invoked a concept of 'good faith', unadorned by any epithet, which 'forbids either party by concealing what he privately knows, to draw the other into a bargain, from his ignorance of that fact, and his believing the contrary. ${ }^{11}$ Nor does Lord Mansfield's judgment break new ground in English jurisprudence in connecting the requirement to disclose information with a principle of good faith. In the unreported 1743 case of Rooke $v$ Thurmond, ${ }^{12}$ the defendant reinsured a voyage policy on a ship but refused to honour a claim for a total loss by capture on the basis that at the time of taking out the reinsurance the claimant knew but failed to inform the defendant that the insured ship was already overdue. Lee CJ held that in principle the alleged facts established a good defence because 'these Contracts are made upon mutual Faith and Credit, and ... to conceal such Circumstances, which may make any Difference in the Adventure, is fraudulent, for the Insurer ought to have the Advantage of Judgment upon them'.

For Lord Mansfield, the injunction against concealment was not confined to insurance contract law: 'The governing principle is applicable to all contracts and dealings.' ${ }^{13}$ This proposition, of course, did not survive. Instead, English contract law as a general proposition endorsed the right to profit from information advantage, 'preferring the benefits of simplicity and certainty which flow from requiring those engaging in commerce to look after their own interests.' ${ }^{14}$ That obviously did not mean that English contract law endorsed bad faith, either generally or in the specific context of contractual negotiations. Notably, active misleading into a contract triggered rights of recourse for misrepresentation at common law in cases of fraud or where the misrepresentation resulted in a total failure of consideration, ${ }^{15}$ and more broadly in equity, ${ }^{16}$ but there

\footnotetext{
${ }^{8}$ MS Harleian 5103, para 35 (likewise MS Additional 48023, para 39), reproduced in G Rossi, Insurance in Elizabethan England (Cambridge, Cambridge University Press, 2016) 546-47.

${ }^{9}$ Rossi (n 8) 245.

${ }^{10} \mathrm{JP}$ van Niekirk, The Development of the Principles of Insurance Law in the Netherlands from 1500 to 1800 (Cape Town, Juta \& Co Ltd, 1998) 494-97, 501. This was the approach of most legislation of the time. In contrast, the Ordinance of Bilbao 1573, having specifically addressed insurance after loss or after safe arrival, contemplated a more general disclosure obligation. By virtue of Art XXVIII, the insurer and assured 'ought, when they shall go sign a Policy, or to treat, and agree on the Premium, to manifest to the Person, who shall intervene, the good, or bad Advices that they shall have of the Ship, and Cargo; that they may thereon treat of an Agreement for the Premium.

${ }^{11}$ Carter (n 2) 1910; 1164.

${ }^{12}$ Postlethwayt (n 5) sv 'Assurance' and 'Further Remarks'; N Magens, An Essay on Insurances (London, J Haberkorn, 1755) vol 1, 85.

${ }^{13}$ Carter (n 2) 1910; 1164. Even this is foreshadowed in earlier case law. The year before Carter v Boehm, in Hodgson

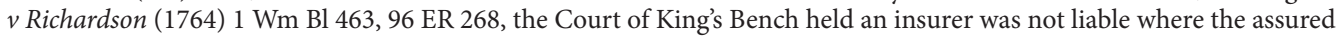
had stated the port of loading to be Genoa whereas in truth it was Leghorn. Yates J, analysing the case as non-disclosure of Leghorn as the port of loading, stated as follows (ibid 465; 269): 'The concealment of material circumstances vitiates all contracts, upon the principles of natural law. A man, if kept ignorant of any material ingredient, may safely say it is not his contract.' Lord Mansfield analysed the case as misrepresentation of Genoa as the port of loading, and therefore did not address non-disclosure.

${ }^{14}$ Manifest Shipping Co Ltd v Uni-Polaris Insurance Co Ltd (The Star Sea) [2001] UKHL 1, [2003] 1 AC 469 [45] (Lord Hobhouse).

${ }^{15}$ Kennedy v Panama, New Zealand \& Australian Royal Mail Co (Ltd) (1866-67) LR 2 QB 580, 587.

${ }^{16}$ Reese River Silver Mining Co Ltd $v$ Smith (1869) LR 4 HL 64, 79-80; Lamare v Dixon (1873) LR 6 HL 414; Redgrave $v$ Hurd (1881) 20 Ch D 1 (CA).
} 
was no culpability in failing to volunteer disclosure of information germane to a prospective transaction. ${ }^{17}$ Insurance contract law, however, made this additional demand, requiring complete openness and the spontaneous disclosure of information material to the risk regardless of potential resulting prejudice to the assured through a refusal of cover or less favourable terms. ${ }^{18}$

With respect to the origin of the phrase, Lord Hobhouse in The Star Sea ${ }^{19}$ suggested that:

It was probably the need to distinguish those transactions to which Lord Mansfield's principle still applied which led to the coining of the phrases 'utmost' good faith and 'uberrimae fidei', phrases not used by Lord Mansfield and which only seem to have become current in the 19th century.

He also attributed the first reported judicial use of such a phrase to Rolfe B in Dalglish v Jarvie ${ }^{20}$ in $1850 .^{21}$

This historical account is, however, at least partly inaccurate. Any accolade for first judicial use of the phrase 'utmost good faith' or its Latin equivalent belongs not, as asserted, to Rolfe B in 1850 but rather to Buller J in the 1798 case of Wolff $v$ Horncastle. ${ }^{22}$ The context, moreover, was not the pre-formation disclosure of information to the insurer, but legislative compliance in the wording of marine policies. The Insurances on Ships etc Act $1785^{23}$ was passed to preclude the issuing of policies in blank that failed to identify the assured, a practice that was conducive to fraud. The terms of the 1785 Act proved unduly restrictive, however, and after only three years it was repealed and replaced by the Marine Insurance Act $1788 .^{24}$ The issue in Wolff $v$ Horncastle was whether a cargo policy satisfied the requirements of the later statute. Buller J outlined the following approach to the legislation:

Now we are bound to say that this second statute must receive the most liberal construction that the words will bear. From the language of the two statutes, as well as the consideration that we are construing a contract uberrimae fide; viz. a policy of insurance, we must avoid bearing harder upon the Plaintiffs than is absolutely necessary. ${ }^{25}$

\footnotetext{
${ }^{17}$ See notably: Fox v Mackreth (1788) 2 Bro CC 400, 420; 29 ER 224, 234; Turner v Harvey (1821) Jac 169, 178; 37 ER 814, 817-18; Walker v Jackson (1842) 10 M \& W 161, 168-69; 152 ER 424, 427-28; Keates v Earl of Cadogan (1851) 10 CB 591, 138 ER 234; Walters v Morgan (1861) 3 De G F \& J 718, 723; 45 ER 1056, 1058-59; Ward v Hobbs (1878) 4 App Cas 13 (HL) 26.

${ }^{18}$ Although the assured's disclosure obligation as it was developed in the 19th century came to exhibit a severity beyond that contemplated by Lord Mansfield: R Hasson, 'The Doctrine of Uberrima Fides in Insurance Law - A Critical Evaluation' (1969) 32 MLR 615. Notably, for fear of encouraging the deliberate withholding of information, the courts became less receptive to arguments that the insurer ought to have known of a particular circumstance so that it did not need to be brought to the insurer's attention by the assured: contrast Bates $v$ Hewitt (1867) LR 2 QB 595 (QB) with the facts of and result in Carter (n 2) itself.

${ }^{19}$ The Star Sea (n 14) [44].

${ }^{20}$ Dalglish v Jarvie (1850) 2 Mac \& G 231, 42 ER 89.

${ }^{21}$ Likewise J Botes, From Good Faith to Utmost Good Faith in Marine Insurance (Frankfurt am Main, Peter Lang, 2006) 85.

${ }^{22}$ Wolff $v$ Horncastle (1798) 1 Bos \& P 316, 126 ER 924

${ }^{23} 25$ Geo III, c 44.

${ }^{24} 28$ Geo III, c 56.

${ }^{25}$ Wolff (n 22) 1 Bos \& P 316, 322; 126 ER 924, 928. Absent this reference to utmost good faith from Buller J, the accolade for first mention would still not go to Rolfe B, but to Best CJ. In Palmer v Pratt (1824) 2 Bing 185, 130 ER 277, it was held that no claim could be made under an insurance policy covering the non-occurrence of a contingency that triggered payment under bills of exchange when the bills in question proved to be a nullity. Best CJ commented (ibid 191; 279) that: 'I regret that we are compelled to come to this decision, because insurance transactions ought to be conducted uberrimâ fide; but the [use of insurance policies to back up bills of exchange] is a new practice, and the parties who engage in it must take the consequence.' In Williams $v$ Rawlinson (1825) 3 Bing 71, 130 ER 440, moreover, the provider of a bond alleged deception as to the secured indebtedness. In rejecting this defence on the facts, Best CJ stated: 'It has been argued, that the Defendant's undertaking is analogous to an insurance; a transaction, in which, according to Lord Mansfield, there must always be uberrima fides.' The reference is to Carter $v$ Boehm, as indicated by the continuation 'but the same learned
} 
Utmost good faith was invoked, therefore, as an aid to statutory interpretation. There is, moreover, no indication that Buller J considered he was introducing a novelty of either substance or rhetoric. On the contrary, he appears to be praying in aid a characteristic of insurance contracts that requires no explanation and by means of a phrase that will be readily recognised. While the precise timing of and context for the initial association of insurance contracts with the phrase 'utmost good faith' remain unknown, it probably pre-dates the emergence of a clear contrast between general contract law and insurance contract law with respect to information advantage.

Two further points may be made about the relationship between the idea of 'utmost good faith' and insurance contract law in the nineteenth century. First, the phrase 'utmost good faith' was not associated uniquely or even primarily with insurance law. Instead, wherever the context rendered it appropriate to require full frankness and openness, to the prejudice, if necessary, of one's own interests, reference might be made to utmost good faith. In addition to insurance contracts, the phrase was pressed into service in connection with partnerships, ${ }^{26}$ the obtaining by a fiduciary of full informed consent for a transaction otherwise in breach of fiduciary duty, ${ }^{27}$ compliance with a trustee's duties,${ }^{28}$ suretyship agreements, ${ }^{29}$ patent applications, ${ }^{30}$ the promotion of companies, ${ }^{31}$ the proposal by a debtor of a scheme of arrangement with creditors, ${ }^{32}$ an application for an injunction ${ }^{33}$ and the obtaining of probate. ${ }^{34}$

Secondly, in the context of insurance contracts, the idea of an enhanced standard of good faith was most commonly associated with pre-formation disclosure obligations, ${ }^{35}$ but not exclusively. The order for ship's papers was an order for accelerated, extended disclosure of documents relevant to a claim on a marine policy developed at common law at a time when conventional disclosure orders were available only from courts of equity. ${ }^{36}$ The commercial justification lay

person, upon the occasion in which he established that position, referred also to the maxim, aliud est tacere, aliud celare'. See Carter (n 2) 1910; 1164. For other references to an enhanced standard of good faith pre-dating the judgment of Rolfe B in Dalglish (n 20), see Hercules Insurance Co v Hunter (1836) 14 S 1137 (IH) 1140 (Lord Moncreiff) ('the strictest equity', 'the most rigid good faith'); Wainewright v Bland (1835) 1 Mood \& R 481, 486; 174 ER 165, 167-68 (Lord Abinger) ('the greatest good faith').

${ }^{26}$ Clements $v$ Hall (1858) 2 De G \& J 173, 188; 44 ER 954, 960; Tennent $v$ Tennent's Trustees (1870-75) LR 2 Sc 6 (HL) 10; Barnes $v$ Youngs [1898] 1 Ch 414 (Ch) 419.

${ }^{27}$ McPherson v Watt (1877) 3 App Cas 254 (HL) 266; Dean v Macdowell (1878) 8 Ch D 345 (CA) 350-51; Law v Law [1905] 1 Ch 140 (CA) 148.

${ }^{28}$ Fraser $v$ Murdoch (1880) 7 R 694 (IH) 711.

${ }^{29}$ Newton $v$ Chorlton (1853) 10 Hare 646, 649; 68 ER 1087, 1088-89, referring also to the extensive disclosure obligation stated in Owen v Homan (1851) 3 Mac \& G 378, 42 ER 307, where a comparison was drawn with insurance (ibid 397; 315).

${ }^{30}$ Sturz v De La Rue (1828) 5 Russ 322, 327; 38 ER 1048, 1050; Re Clark's Patent (1870) 7 Moo PC NS 255, 262; 17 ER 97, 100; Re Pitman's Patent (1871) LR 4 PC 84, 86.

${ }^{31}$ Ross v Estates Investment Co (1866) LR 3 Eq 122 (Ch) 136; Erlanger v New Sombrero Phosphate Co (1878) 3 App Cas 1218 (HL) 1255.

${ }^{32}$ Re Moon (1887) 19 QBD 669 (CA) 672.

${ }^{33}$ Dalglish (n 20) 243-44; 94 . See also $R$ v Kensington Income Tax Commissioners, ex parte Princess Edmond de Polignac [1917] 1 KB 486 (CA) (writ of prohibition).

${ }^{34}$ Attorney-General v Smith \& Cocks [1892] 2 QB 289 (QB) 293.

${ }^{35}$ Fawcus v Sarsfield (1856) 6 El \& Bl 192, 202; 119 ER 836, 839-40; Wheelton v Hardisty (1857) 8 El \& Bl 232, 270; 120 ER 86, 101; Belfast \& Ballymena Railway Co v Keys (1861) 9 HLC 556, 563; 11 ER 846, 849; Gandy v Adelaide Marine Insurance Co (1871) LR 6 QB 746 (QB) 758; Life Association of Scotland v Foster (1873) 11 M 351 (IH) 359; Robinson $v$ Mollett (1874) LR 7 HL 802, 817; Lishman v Northern Maritime Insurance Co (1875) LR 10 CP 179, 182; London Assurance Co v Mansel (1879) 11 Ch D 363 (Ch) 368; Brownlie v Campbell (1880) 5 App Cas 925 (HL) 954; Blackburn Low \& Co $v$ Vigors (1886) 17 QBD 553 (CA) 584.

${ }^{36}$ Goldschmidt v Marryat (1809) 1 Camp 558, 170 ER 1057; Leon v Casey [1932] 2 KB 576 (CA) 579-81; Probatina Shipping Co Ltd v Sun Insurance Office Ltd (The Sageorge) [1974] QB 635 (CA) 641. Because it was designed to enable insurers to assess a claim, the order was available as soon as proceedings had been commenced by the assured, with no requirement for the insurer first to serve a defence. The order was directed at the assured but instructed disclosure of relevant documents in the possession of not only the assured but also any other party, or provision of evidence of having tried to obtain them, albeit unsuccessfully. 
in the practical disadvantage faced by marine insurers from the potential for the circumstances surrounding the casualty to be predominantly and particularly within the knowledge of the assured. In terms of legal principle, however, reference was made to enhanced good faith to justify the timing and extent of the order, ${ }^{37}$ and perhaps also to emphasise the limits of the encroachment by the common law courts onto previously equitable territory.

An enhanced standard of good faith was invoked also in connection with fraudulent claims. In Britton $v$ Royal Insurance $\mathrm{Co},{ }^{38}$ a policy against loss by fire provided that a fraudulent claim would render the policy void. In addressing the jury, Willes J emphasised that a claim was no less fraudulent even if the loss had not been wilfully procured but the assured had wilfully inflated the extent of the loss sustained by reason of a genuine casualty:

The law upon such a case is in accordance with justice, and also with sound policy. The law is, that a person who has made such a fraudulent claim could not be permitted to recover at all. The contract of insurance is one of perfect good faith on both sides, and it is most important that such good faith should be maintained. It is the common practice to insert in fire-policies conditions that they shall be void in the event of a fraudulent claim; and there was such a condition in the present case. Such a condition is only in accordance with legal principle and sound policy. It would be most dangerous to permit parties to practise such frauds, and then, notwithstanding their falsehood and fraud, to recover the real value of the goods consumed. ${ }^{39}$

Fundamentally, therefore, an assured could not be allowed to think that a genuine claim could be fraudulently exaggerated without penalty. Law that allowed the assured still to recover an indemnity for the true loss would provide no deterrent against fraud and could even incentivise it. This simple point does not depend on a concept of enhanced good faith, but its invocation served perhaps to reinforce the repugnance of fraud to insurance.

What, then, was the role of 'utmost good faith' with respect to insurance contract law during the first age of its existence? A key question is the basis and rationale for the central duty associated with the concept of utmost good faith, namely the assured's pre-formation disclosure obligation. Recognition of this obligation resulted from the fact that an insurer in essence invested in a package of information the content of which it had to take largely on trust. The insurer assessed and priced risk acceptance necessarily in reliance on the description provided by the assured, more rigorous due diligence often being rendered difficult or impossible by the geographically remote location of the insured property, by the lack of tangible manifestation susceptible to inspection of relevant circumstances, such as those pertaining to moral hazard, or by market expectation and practice as to the rapidity of insurers' decision-making. ${ }^{40}$ This was, indeed, the foundation for Lord Mansfield's exposition of principle in Carter $v$ Boehm: ${ }^{41}$

Insurance is a contract upon speculation. The special facts, upon which the contingent chance is to be computed, lie most commonly in the knowledge of the insured only; the under-writer trusts to his

\footnotetext{
${ }^{37}$ Rayner v Ritson (1865) 6 B \& S 888, 890-91; 122 ER 1421, 1421-22 (Cockburn CJ): 'The exceptional practice in these cases seems to have arisen out of the particular nature of the contract of insurance. The underwriter of a policy of marine insurance who is sued for a constructive total loss of the ship is so much at the mercy of the assured with respect to the circumstances under which the vessel has been abandoned, and there ought to be uberrima fides on the part of the latter, and he ought therefore to lay those circumstances before the underwriter.' See also China Traders' Insurance Co Ltd v Royal Exchange Assurance Corp [1898] 2 QB 187 (CA) 193-94; Boulton v Houlder Bros \& Co [1904] 1 KB 784 (CA) 791-92; Harding $v$ Bussell [1905] 2 KB 83 (CA) 85-86.

${ }^{38}$ Britton v Royal Insurance Co (1866) 4 F \& F 905, 176 ER 843.

${ }^{39}$ ibid 909; 844.

${ }^{40}$ North Star Shipping Ltd $v$ Sphere Drake Insurance plc (No 2) [2005] EWHC 665 (Comm), [2005] 2 Lloyd's Rep 76 [256]; Versloot Dredging BV v HDI Gerling Industrie Versicherung AG (The DC Merwestone) [2016] UKSC 45, [2017] AC 1 [114].

${ }^{41}$ Carter (n 2) 1909; 1164.
} 
representation, and proceeds upon confidence that he does not keep back any circumstance in his knowledge, to mislead the under-writer into a belief that the circumstance does not exist, and to induce him to estimate the risque, as if it did not exist.

Moreover, whilst the operative concept was said to be 'concealment' and whilst non-disclosure was sometimes described as 'fraudulent', any 'deception' reflected the erroneous picture in the mind of the insurer rather than any moral culpability attaching to the assured for duplicity or sharp practice in engendering that false understanding: ${ }^{42}$ such 'fraud', therefore, 'was not actual fraud as known to the common law but a form of mistake of which the other party was not allowed to take advantage. ${ }^{3}$ The assured was not allowed to take advantage of a misapprehension on the part of the insurer resulting from information disadvantage.

The reasoning, therefore, was that the commercial realities of insurance required a distinctive regime of disclosure obligations, which then attracted the rhetorical label 'utmost good faith'. English law did not recognise 'utmost good faith' as a characteristic of certain contracts, which in turn triggered the applicability of pre-formation disclosure obligations. 'Utmost good faith', in short, was little more than a slogan describing a legal response to the transactional dynamic between the parties to an insurance contract. ${ }^{44}$ The normative underpinnings for the assured's disclosure obligations lay in that dynamic, not some abstract status of insurance contracts as 'of the utmost good faith'.

Nor do the references to utmost good faith in other contexts indicate a significant normative potency. When the practice of making extended disclosure orders for ship's papers was challenged in 1809 , the practice was justified by Sir James Mansfield CJ by pointing to the practical disadvantages of being compelled to follow the standard procedure of seeking disclosure in equity. ${ }^{45}$ No reference was made to (marine) insurance contracts being of the utmost good faith. That gloss was added only some decades later. As noted above, the judgment of Willes J in Britton $v$ Royal Insurance $\mathrm{Co}^{46}$ on fraudulent claims is based on sound, pragmatic concerns relating to deterring fraud. Utmost good faith, although rhetorically flourished, contributes nothing of itself. Equally, garnishing the inability to recover for losses caused by the wilful misconduct of the assured with the 'greatest good faith' that is required of an assured ${ }^{47}$ adds nothing to the public policy and construction barriers to recovery. ${ }^{48}$ Likewise, the decision in Wolff $v$ Horncastle ${ }^{49}$ is founded on the background to and wording of the relevant legislation.

Utmost good faith was, admittedly, invoked in Wolff as at least burnishing the lens through which the legislation should be read, but a less welcoming approach was evidenced by the Privy Council in Beacon Life \& Fire Assurance Co $v$ Gibb with respect to policy interpretation. ${ }^{50}$ A policy form designed for house insurance was used for the insurance of a vessel. The policy excluded liability for any loss occurring at a time when more than $20 \mathrm{lb}$ of gunpowder were 'on the premises'. At the time of the loss, the vessel's cargo included more than $20 \mathrm{lb}$ of gunpowder. The Canadian

\footnotetext{
${ }^{42}$ ibid (Lord Mansfield): 'Although the suppression should happen through mistake, without any fraudulent intention; yet still the under-writer is deceived, and the policy is void; because the risque run is really different from the risque understood and intended to be run, at the time of the agreement.'

${ }^{43}$ The Star Sea (n 14) [42] (Lord Hobhouse).

${ }^{44}$ See also A Forte, 'Good Faith and Utmost Good Faith: Insurance and Cautionary Obligations in Scots Law' in A Forte (ed), Good Faith in Contract and Property Law (Oxford, Hart Publishing, 1999) 81-86.

${ }^{45}$ Goldschmidt (n 36).

${ }^{46}$ Britton (n 38).

${ }^{47}$ Wainewright (n 25) 486; 167-68 (Lord Abinger).

${ }^{48}$ Beresford v Royal Insurance Co Ltd [1938] AC 586 (HL); Porter v Zurich Insurance Co [2009] EWHC 376 (QB), [2009]

2 All ER (Comm) 658.

${ }^{49}$ Wolff (n 22).

${ }^{50}$ Beacon Life \& Fire Assurance Co v Gibb (1862) 1 Moo PC NS 73, 15 ER 630.
} 
appellate court held the exclusion inapplicable given that the policy did not preclude the carriage of gunpowder and that its presence on board did not cause the loss. A denial of indemnification in such circumstances would be contrary to good faith in the absence of more specific wording. According to Badgley J:

The law of insurance requires uberrima fides from the insured. The like is or should be imposed upon the insurers, who should have stipulated their refusal to allow gunpowder to be carried as freight. It was in their power to condition their own risk in this respect, and to render the condition plain, precise, and positive, instead of leaving it uncertain and doubtful, and contrary to law, casting the doubt from themselves upon the insured. The rule of law should be held against them. The construction of the contract must be strictly against those for whose benefit the conditions are introduced when they impose burdens on the parties; otherwise, fraud would be paramount, to the exclusion of good faith. ${ }^{51}$

The Privy Council, however, adopted a different approach and upheld the insurers' appeal. The exclusion was unambiguous on its wording and applicable. The only way to avoid the exclusion was to import additional words that would change its meaning, for which there was no licence. Neither the exclusion's wording nor insurance law principle rendered causation of any relevance. Whatever the potential for utmost good faith to influence construction of less clearly worded policies, as to which the Privy Council was silent, a general concept of utmost good faith could not impinge on unambiguous wording.

In conclusion, while encapsulating by way of useful shorthand the law's adoption of especially stringent standards in the context of the negotiation of insurance cover, ${ }^{52}$ the concept of utmost good faith in its first age lacked normative potency of itself and exerted at most a marginal influence on the development of insurance law doctrine. The idea that insurance contracts are contracts of the utmost good faith certainly seems to have provided welcome support in a variety of contexts, but there is no indication that this idea made a decisive contribution to the courts' thinking. In short, even without the recognition of a general concept or idea of 'utmost good faith', insurance contract law would probably have developed in an identical fashion up to the beginning of the twentieth century.

\section{The Second Age: The Marine Insurance Act 1906}

The advent of the Marine Insurance Act 1906 heralded a change in the status and prominence of the concept of utmost good faith. In the scheme of Sir Mackenzie Chalmers, the concept was elevated to a fundamental, organising principle of insurance law. ${ }^{53}$ A group of sections collectively headed 'Disclosure and Representations' is introduced by section 17, which carries the marginal heading 'Insurance is uberrimae fidei' and which provides as follows:

A contract of marine insurance is a contract based upon the utmost good faith, and, if the utmost good faith be not observed by either party, the contract may be avoided by the other party.

\footnotetext{
${ }^{51}$ ibid 85-86; 634-35.

${ }^{52}$ Seaton $v$ Heath [1899] 1 QB 782 (CA) 792 (Romer LJ: uberrima fides a 'short and convenient' expression, denoting the requirement that an assured 'in setting forth the risk to be insured against, not conceal any material fact affecting the risk known to him').

${ }^{53}$ The relevant provisions of the 1906 Act state for the purposes of marine insurance contracts principles that it is accepted are applicable to all insurance contracts: Joel v Law Union \& Crown Insurance Co [1908] 2 KB 863 (CA); Lambert $v$ Co-op Insurance Society Ltd [1975] 2 Lloyd's Rep 485 (CA); Pan Atlantic Insurance Co Ltd v Pine Top Insurance Co Ltd [1995] 1 AC 501 (HL) 518.
} 
Utmost good faith in the era of the 1906 Act presents, nevertheless, a structural puzzle, namely the relationship between the utmost good faith of which section 17 speaks and all aspects of utmost good faith as recognised in insurance contract law. There are two possibilities. The first is that section 17 acts as an umbrella provision for the entirety of the doctrine, including those aspects of the doctrine which are addressed explicitly by the 1906 Act and other aspects in respect of which the Act is silent. The second is that the doctrine of utmost good faith is broader than section 17, which acts as an umbrella provision for certain aspects of the doctrine that attach to the negotiation of an insurance contract or its variation but which leaves other aspects free to develop outside the confines of that section.

Fundamental to this question is the issue of remedy. Section 17 provides unambiguously that a failure by either party to meet the requirements of utmost good faith affords the other party the right retrospectively to avoid the contract. In the context of insurance contracts, such avoidance is usually invoked by an insurer in the light of circumstances discovered when investigating a claim and will retrospectively deprive the assured of cover at a time when it is too late to obtain alternative insurance. In addition, the insurer will be entitled to repayment of any sums paid in satisfaction of previous claims. The question of the precise role and scope of section 17 is fundamentally about the availability of this remedy that, within the framework of general contract law, responds to a defect in the formation of the contract.

It is convenient to consider the structural issues generated by section 17, and thereby the role of utmost good faith in its second age, by distinguishing between utmost good faith before the formation of an insurance contract and utmost good faith during the lifetime of an insurance contract after it has been created. Some conclusions will then be drawn.

\section{A. Pre-formation Utmost Good Faith}

Utmost good faith in the pre-formation stage relates to the initial presentation of a risk to an insurer prior to the formation of an insurance contract. Section 18 addresses the assured's pre-formation disclosure obligation, section 19 disclosure by an agent effecting insurance on behalf of the assured and section 20 misrepresentation by either the assured or an agent. These sections, it has been consistently averred, articulate aspects of the broader doctrine of utmost good faith as stated by section $17 . .^{54}$

This analysis of the assured's obligations of disclosure under section 18 and truth of representation under section 20 is uncontroversial on the wording of the relevant sections, which accurately reflect the earlier case law they codify. As already discussed, utmost good faith became part of the language of insurance contract law primarily, although not exclusively, to highlight the assured's pre-formation disclosure obligations. Section 19, however, is more difficult. It addresses disclosure where insurance is effected, as is almost invariably the case, through a broker. The circumstances that require disclosure include those which are in fact known by the broker and those which ought to be known by or to have been communicated to the broker, irrespective of whether the broker's knowledge, actual or constructive, arose in the context of the broker's

\footnotetext{
${ }^{54}$ Container Transport International Inc v Oceanus Mutual Underwriting Association (Bermuda) Ltd (No 1) [1982] 2 Lloyd's Rep 178 (Com Ct) 187, [1984] 1 Lloyd's Rep 476 (CA) 492, 496, 512, 525; Société Anonyme d'Intermediaries Luxembourgeois (SAIL) v Farex Gie [1995] LRLR 116 (CA) 142; PCW Syndicates v PCW Reinsurers [1996] 1 WLR 1136 (CA) 1145; Group Josi Re Co SA v Walbrook Insurance Co Ltd [1996] 1 WLR 1152 (CA) 1170.
} 
agency for the assured. Critically, section 19 is construed as addressing a disclosure obligation owed personally by a placing broker to the insurer. The broker's knowledge is not attributed to the assured. ${ }^{55}$ Otherwise, section 19 would be otiose, since the knowledge of the agent would fall within the scope of the assured's disclosure obligation. ${ }^{56}$ Section 17 refers, however, to the observance of utmost good faith by the parties to the contract. Section 19 is concerned with the observance of utmost good faith in relation to an insurance contract, but not by a party to that contract. It would be possible to connect non-disclosure by the broker with a failure on the part of the assured to observe the utmost good faith if that doctrine generated an implied undertaking by the assured in an insurance contract that there had been no failure to make due disclosure by either the assured or the broker. While, however, there was some support for such an approach in the nineteenth century, ${ }^{57}$ it is now settled that the pre-formation duties relating to disclosure and truth of statements arise as a matter of law as legal incidents to the negotiation of an insurance contract, and do not operate by means of implied terms. This is consistent specifically with non-compliance giving rise to a right of avoidance, rather than a remedy for breach of a contractual term, ${ }^{58}$ and more broadly with general (contract) law. ${ }^{59}$ The conclusion has to be that section 19 , as understood by the case law, does not fit within section 17. The placing broker's duty of disclosure forms part of the doctrine of utmost good faith, but outside of section $17 .{ }^{60}$

The disclosure obligations that attach to the initial negotiation of an insurance contract manifest the law's rejection of a right on the part of the assured to benefit from information advantage. When deciding whether to accept the presented risk and, if so, on what terms, the insurer is entitled to parity of information with the assured and the placing broker. That entitlement applies equally on any subsequent occasion on which the assured asks the insurer to make an underwriting decision, namely a decision about acceptability of additional or altered risk and/or the terms of acceptance of such risk. Consequently, disclosure of material circumstances as well as truth of statements is required if the assured requests the insurer to vary an existing contract of insurance. How does this duty of disclosure fit into the doctrine of utmost good faith and the provisions of the 1906 Act? Section 17 provides by way of remedy for failure to observe the utmost good faith that 'the contract may be avoided'. The relationship between utmost good faith as attaching to variations of cover and section 17 depends on what is meant by 'the contract': in the context of a variation, does it mean the original contract or only the variation?

\footnotetext{
${ }^{55}$ Blackburn Low \& Co v Vigors (1887) 12 App Cas 531 (HL) 542-43; El Ajou v Dollar Land Holdings plc (No 1) [1994] 2 All ER 685 (CA) 702; SAIL (n 54) 142-43, 150; PCW Syndicates (n 54) 1145.

${ }^{56}$ SAIL (n 54) 150.

${ }^{57}$ Blackburn Low \& Co (CA) (n 35) 562-63, 578 .

${ }^{58}$ Banque Keyser Ullmann SA v Skandia (UK) Insurance Co Ltd [1990] 1 QB 665 (CA) 702 (Steyn J), 779-80 (Slade LJ); The Star Sea (n 14) [46], [52].

${ }^{59} \mathrm{See}$, eg the remedial consequences of incorporation of a misrepresentation as a term of the contract.

${ }^{60}$ The structural issue raised in the text could perhaps be avoided by a different reading of the legislation. Arguably, s 18 should apply where the assured places the insurance directly with the insurer, while s 19 should apply instead, to the exclusion of s 18, where, as in practice is invariably the case with commercial policies, the insurance is placed by a broker acting on behalf of the assured. In such a case, the disclosure obligation would extend, as stated by s 19 , to any material circumstance either (a) within the broker's actual and constructive knowledge or (b) that would fall to be disclosed by the assured under s 18 if that section applied provided it came to the assured's knowledge in time to communicate to the broker for disclosure by the broker to the underwriter. Non-disclosure by the broker would be attributable to the assured in accordance with general agency principle and naturally render the policy voidable. On the prevailing analysis, it is puzzling why the breach of a duty owed independently by the broker, and not qua agent of the assured, should prejudice the assured's contract, especially given the rejection of an implied term analysis. A different approach would also explain why there is no reference in the Act to misrepresentation by the broker. Section 20 refers to misrepresentation 'by the assured or his agent', but if the broker owes an independent duty to the insurer in respect of disclosure, it must also owe a parallel independent duty in respect of representations which is not encompassed by a reference to agency.
} 
One must first clarify the precise consequences of non-disclosure (or misrepresentation) in the context of a policy variation. It is clear that the disclosure obligation attaching to a variation is restricted in scope to circumstances material to the variation and does not extend to circumstances material not to the variation but to the original risk. Disclosure being designed to produce parity of information relating to an underwriting decision, once that decision is taken the obligation to disclose information material to it ceases. The scope of any new disclosure obligation subsequently arising in relation to a new underwriting decision is then delineated by what is material to that decision. ${ }^{61}$ Similarly, the requirement for subjective inducement of the insurer's decision to contract on the terms agreed, recognised as necessary to render a non-disclosure or misrepresentation actionable in the context of the original formation of an insurance contract, ${ }^{62}$ applies equally to variations of cover. There can be no remedy unless the non-disclosure or misrepresentation material to the variation in fact induced the insurer into the variation. ${ }^{63}$ Equally, the remedy for non-disclosure must reflect the context of the wrong. What is vitiated is the underwriting decision in relation to which the insurer was denied the parity of information to which it was entitled, ie the decision that was induced by the denial of (accurate) information material to it. The remedy should be the reversal of that decision. ${ }^{64}$ In a case of non-disclosure or misrepresentation in relation to a variation, avoidance of not just the variation but of the original policy itself would be both illogical and indefensibly disproportionate and punitive. ${ }^{65}$

This may be achieved within the terms of section 17 on the basis that a variation constitutes an independent, severable contract that attaches to the original contract but can be detached from it by avoidance. ${ }^{66}$ In the context of a variation, 'the contract' that section 17 states may be avoided in the event of a failure to observe the utmost good faith is the contract to vary. Variations, therefore, give rise to a standard application of the pre-formation doctrine of utmost good faith and of sections $18-20$ of the 1906 Act. ${ }^{67}$

In the above discussion, section 17 itself and the concept of utmost good faith have little substantive impact. The duties whose breach may be asserted by an insurer are articulated by sections 18-20, which also reiterate the remedy of avoidance. Nevertheless, while utmost good faith constitutes a broad, organising principle (albeit that the placing broker's duties do not fit within the drafting of section 17), in certain respects section 17 fulfils an independent function. First, section 17 articulates the mutual nature of the doctrine: the insurer owes the assured reciprocal obligations of disclosure and truth of statement. The following sections are confined to the obligations owed by the assured and the placing broker. Although not prominent in the case law, insurers were known on occasion to exploit an information advantage in relation to the fact that the vessel or cargo presented for insurance had already arrived safely and to accept premium for, in truth, no assumption of risk. ${ }^{68}$ Secondly, sections $18-20$ confer a remedy in relation to

${ }^{61}$ Lishman (n 35) 182; Iron Trades Mutual Insurance Co Ltd v Companhia de Seguros Imperio [1991] 1 Re LR 213 (Com Ct) 224; Black King Shipping Corp v Massie (The Litsion Pride) [1985] 1 Lloyd’s Rep 437 (Com Ct) 511.

${ }^{62}$ Pan Atlantic Insurance (n 53).

${ }^{63}$ AC Ward \& Son Ltd v Catlin (Five) Ltd (No 2) [2009] EWHC 3122 (Comm), [2010] Lloyd's Rep IR 695 [195].

${ }^{64}$ Container Transport (Com Ct) (n 54) 191-92; AC Ward \& Son Ltd (n 63) [233].

${ }^{65}$ K/S Merc-Scandia XXXXII v Lloyd's Underwriters (The Mercandian Continent) [2001] EWCA Civ 1275, [2001] 2 Lloyd's Rep 563 [22(2)].

${ }^{66}$ Occidental Worldwide Investment Corp v Skibs A/S Avanti (The Siboen and the Sibotre) [1976] 1 Lloyd's Rep 293 (Com Ct) 340 .

${ }^{67}$ See, eg, Fraser Shipping Ltd $v$ Colton [1997] 1 Lloyd's Rep 586 (Com Ct), in which the assured's notification of a change of voyage was too late to comply with the terms of a held covered clause (analysed below). The notification therefore constituted a request for a variation of terms. Without analysis, the court, correctly it is suggested, applied s 18 to the assured's disclosure obligations.

${ }^{68}$ Carter (n 2) 1909; 1164. 
non-disclosure or misrepresentation of a 'material' circumstance. Section 17 contains no reference to materiality and would have to be the basis for any right of avoidance in the event of non-disclosure or misrepresentation not dependent on proof of materiality. It is clear that a fraudulent assured cannot resist avoidance on the basis that the concealed or misstated circumstance lacked materiality. The weight of authority supports the simple technical explanation that materiality is not required as a matter of principle, ${ }^{69}$ in which case section 17 would have to apply, although it is possible that materiality is notionally required but a fraudulent assured is not permitted to deny the materiality of its fraud, ${ }^{70}$ in which case sections $18-20$ would still apply. Thirdly, where an insurer requests information that does not qualify as material, so that disclosure would not be required in the absence of enquiry, an inaccurate response would fall outside section 20 but render the contract voidable under section $17 .{ }^{71}$ Fourthly, it has been stated that where the assured is aware that the insurer is proceeding on the basis of a mistaken misapprehension as to a material circumstance, such as a level of losses, or has made a material mathematical error, utmost good faith requires the assured to correct the insurer's error, with silence again rendering the policy voidable under section $17 .{ }^{72}$

\section{B. Post-formation Utmost Good Faith}

Once the contract has been concluded, it becomes especially important to distinguish between, on the one hand, the applicability of the doctrine of utmost good faith and, on the other hand, the availability of the remedy of avoidance of the contract prescribed by section 17 . In the pre-formation context, the doctrine is concerned entirely with parity of information in relation to underwriting decisions, with non-observance rendering the contract voidable consistently with the remedial response espoused by general contract law to induced defects in consent to the formation of a contract. In the post-formation context, however, utmost good faith has been invoked in a variety of different contexts, none of which, by definition, are concerned with consent to the formation of a contract. Retrospective avoidance in such contexts would then afford the insurer the right to reclaim payment of any sums previously paid in settlement of genuine claims. The existence and amount of such earlier payments being a matter of happenstance, such financial consequences of avoidance would be arbitrary. They would also be inconsistent with the approach of general contract law, which confines remedies for defects in the performance of a contract to compensation for loss caused by the defective performance and loss of future entitlements. Any adoption by insurance contract law of a stricter remedial regime requires reasoned justification, not merely the brandishing of a rhetorical flourish.

One clear example of post-formation utmost good faith arises where the assured does not request a consensual alteration to the terms of the contract but activates a conditional extension of cover as a matter of right in accordance with the original terms of the policy. Thus, a 'held covered clause' typically provides that, in circumstances in which cover would otherwise prospectively cease (typically by virtue of an alteration of risk or breach of warranty), ${ }^{73}$ cover will instead continue, provided the assured notifies the insurer of the relevant circumstances

\footnotetext{
${ }^{69}$ The Bedouin [1894] P 1 (CA) 12; Gordon v Street [1899] 2 QB 641 (CA); Rafsanjan Pistachio Producers Co-operative $v$ Bank Leumi (UK) Ltd [1992] 1 Lloyd's Rep 513 (Com Ct) 542; Pan Atlantic Insurance (n 53) 533.

${ }^{70}$ The DC Merwestone (n 40) [31].

${ }^{71}$ Haywood v Rodgers (1804) 4 East 590, 102 ER 957; The Bedouin (n 69) 12; Container Transport (CA) (n 54) 512.

${ }^{72}$ Container Transport (CA) (n 54) 512, 522, 525.

${ }^{73}$ Under the 1906 Act, such cessation was permanent unless the contract stipulated to the contrary, while the default rule for breach of warranty is changed by the Insurance Act 2015, s 10 to suspension of cover pending cure of breach.
} 
and agrees to such additional premium and other change of terms as the insurer might reasonably require. ${ }^{74}$ The insurer has no right to decline this extension of cover, provided the assured complies with the stipulated conditions relating to notification and agreement to altered terms. ${ }^{75}$ A held covered clause therefore constitutes an option granted to the assured under the terms of the contract which the assured has the right to trigger by fulfilling the stipulated conditions regarding notification and agreement to alteration of terms. There is no new contract to which the insurer's consent is required. Nevertheless, the setting of appropriate new terms in accordance with the clause constitutes an underwriting decision attracting the right to parity and accuracy of information material to that decision encapsulated by the doctrine of utmost good faith. ${ }^{76}$ In the event of failure to provide full and accurate information, the assured should be denied the benefit of the clause. The failure to observe the utmost good faith does not, however, impugn a decision by the insurer to conclude a new contract, since, as stated, the insurer is already committed to the extension under the terms of the original policy. ${ }^{77}$ Rather, it constitutes a failure to satisfy the agreed requirements for the extension of cover. The logical result, therefore, is that no extension comes into effect. This does not fit section 17, which contemplates instead the vitiating of a decision to contract rendering the resulting contract voidable, not the denial of existing contractual rights. $^{78}$

Beyond underwriting decisions, the key test for the potential post-formation applicability of section 17 is the fraudulent claim. Submitting a fraudulent claim constitutes the most nefarious sin an assured can commit during the lifetime of an insurance contract. If dishonesty in such a core aspect of an insurance contract fails to attract the remedial severity of avoidance, as prescribed by section 17 , then it is difficult to see in what circumstances such a remedial response can ever be justified.

Some parallels can be drawn between the making of a claim and the negotiation of an insurance contract. As at the pre-formation stage, the assured is asking the insurer to make a decision in circumstances where the assured may have an information advantage. Not only may the assured have direct knowledge of the circumstances surrounding the loss, but thorough and independent investigation by the insurer may not be possible. And extensive verification by the insurer is inimical to the expeditious settlement of claims that assureds like to receive and insurers marketing departments like to proclaim. ${ }^{79}$ The demands placed on the assured are not, however, the same. In the claims context, the law does not require disclosure of all circumstances material to assessment of the claim, but instead concerns itself only with fraud, conferring an entitlement on the insurer not to parity of information but only to honesty.

\footnotetext{
${ }^{74}$ The reasonableness limitation is stated in relation to premium by the Marine Insurance Act 1906, s 31(1).

${ }^{75}$ Although the clause cannot operate if its terms cannot accommodate the extended risk. Thus, an extension that would command a reasonable additional premium at least equal to the measure of indemnity for any probable ensuing claim would be self-defeating: Greenock Steamship Co v Maritime Insurance Co Ltd [1903] 1 KB 367 (KB). Likewise, an extension that is uninsurable without an alteration of terms as well as additional premium cannot be accommodated by a clause that provides for additional premium only: Liberian Insurance Agency Inc v Mosse [1977] 2 Lloyd's Rep 560 (QB).

${ }^{76}$ Overseas Commodities Ltd v Style [1958] 1 Lloyd's Rep 546 (Com Ct) 559; Liberian Insurance Agency (n 75) 568.

${ }^{77}$ If a held covered clause gave rise to a distinct contract of variation, the clause itself would be a mere agreement to agree, conferring no rights on the assured.

${ }^{78}$ It follows that waiver would have to work by way of estoppel rather than affirmation as in the case of breach of promissory warranty, as to which see Bank of Nova Scotia v Hellenic Mutual War Risks Association (Bermuda) Ltd (The Good Luck) [1992] 1 AC 233 (HL) 263; Kirkaldy (J) \& Sons Ltd v Walker [1999] EWHC 839 (Comm), [1999] Lloyd's Rep IR 410, 422; HIH Casualty \& General Insurance Ltd v Axa Corporate Solutions [2002] EWCA Civ 1253, [2003] Lloyd's Rep IR 1.

${ }^{79}$ The DC Merwestone (n 40) [9], [55], and see [111] (Lord Mance): 'Insurance is about the assessment of risk and the settlement of claims. Both processes depend on good faith and fair information, and both are normally consensual'. See also Orakpo v Barclays Insurance Services Co Ltd [1995] LRLR 443 (CA) 451.
} 
With respect to remedy, the potential vulnerability of the insurer in relation to dishonest claims, coupled with the law's repugnance of fraud, ${ }^{80}$ generated a rule that fraud in a claim forfeits ${ }^{81}$ all entitlements under the policy that the assured might otherwise have derived from the circumstances giving rise to the claim. Under an indemnity policy, the assured's entitlement to an indemnity arises as soon as an insured loss occurs. Fraud on the part of the assured in generating a casualty will prevent any loss being insured in the first place. ${ }^{82}$ Fraud that subsequently taints a claim in relation to an otherwise insured loss retrospectively removes the assured's rights in relation to that loss. ${ }^{83}$ Two specific points need to be noted. First, the fraudulent exaggeration of a genuine claim entitles the insurer to reject the entirety of the claim, resulting in forfeiture of the genuine part of the claim: 'The logic is simple. The fraudulent insured must not be allowed to think: if the fraud is successful, then I will gain; if it is unsuccessful, I will lose nothing. ${ }^{\text {'4 }}$ Secondly, the insurer is entitled to recover any sums already paid towards satisfaction of a claim before that claim becomes tainted by fraud: ${ }^{85}$ 'There is no obvious reason why the consequences of making a fraudulent claim should depend upon the timing of any payment in respect of any genuine part of the claim. ${ }^{\text {' }}$

This forfeiture rule is a 'special common law rule'87 attaching to the making of claims under insurance contracts which operates independently of any discharge of the contract, whether prospective or retrospective. Forfeiture is not a by-product of discharge for repudiatory breach or avoidance for failure to observe the utmost good faith. It is an incident of insurance contracts born, as stated, of the insurer's dependence on information from the assured and the law's repugnance of fraud. It has, nevertheless, been connected in several judgments to the doctrine of utmost good faith (with reference being made to the judgment of Willes J in Britton $v$ Royal Insurance $\mathrm{Co}^{88}$ ), at least to the extent of the doctrine providing inspiration and support for the rule's development. ${ }^{89}$ And, indeed, insurance contract law departs from the general law of obligations in penalising dishonesty. As several Commercial Court judges observed to the Law Commissions, a personal injury claimant who dishonestly exaggerates the extent of the injuries sustained still recovers damages in respect of the true injuries..$^{90}$ Utmost good faith, in that it encapsulates enhanced legal expectations born of dependence on the other party for critical information in circumstances where the normal expectation of undertaking one's own due diligence is unrealistic, explains insurance law's severity. It has never been authoritatively decided, however, whether a fraudulent claim constitutes a failure to observe the utmost good faith within section 17 of the 1906 Act, so that the insurer will also have a right of retrospective avoidance of the policy. It has, nevertheless, been indicated obiter on several occasions that any further remedial consequence

\footnotetext{
${ }^{80}$ The DC Merwestone (n 40) [9], [94].

${ }^{81}$ ibid [24].

${ }^{82}$ That is not to suggest that the absence of an insured loss means that the law on fraudulent claims does not apply to the ensuing claim.

${ }^{83}$ AXA General Insurance Ltd v Gottlieb [2005] EWCA Civ 112, [2005] Lloyd's Rep IR 369 [26].

${ }^{84}$ The Star Sea (n 14) [62] (Lord Hobhouse).

${ }^{85}$ AXA General Insurance (n 83). Any such sums will be recoverable as paid under a fundamental mistake or on a consideration that has totally failed: [27].

${ }^{86}$ ibid [28] (Mance LJ).

${ }^{87}$ ibid [31] (Mance LJ).

${ }^{88}$ Britton (n 38) (above, text to n 39).

${ }^{89}$ The DC Merwestone (n 40) [8], [67] (but $c f$ [97]: 'related (but distinct)'), [119]. See also Orakpo (n 79) 451.

${ }^{90}$ Law Commission of England and Wales and Scottish Law Commission, Insurance Contract Law: Business Disclosure; Warranties; Insurers' Remedies for Fraudulent Claims; and Late Payment (Law Com No 353, 2014; Scot Law Com No 238, 2014) para 21.16.
} 
beyond the forfeiture rule ought to arise through the normal principles of general contract law, so that any discharge would be prospective on the basis that the fraudulent claim constituted a repudiatory breach of contract. ${ }^{91}$

A discussion of the application of section 17 to post-formation utmost good faith requires reference also to the order for ship's papers. In Sir Mackenzie Chalmers' own commentary on the 1906 Act, he wrote by way of a note to section $17:^{92}$

It follows from the nature of the contract that even in litigation both parties must pay with the cards on the table; hence the full discovery allowed as to ships' papers and other material documents.

As noted above, utmost good faith does indeed contribute to the courts' justification for the exceptional disclosure order that is the order for ship's papers, at least in judgments from the mid-nineteenth century onwards, including after the advent of the 1906 Act. ${ }^{93}$ It has never been suggested, however, that a failure to comply with an order for ship's papers might afford the insurer the right to avoid the policy, ${ }^{94}$ and it would indeed be anomalous and startlingly harsh for non-compliance with one particular form of disclosure order to incur such a draconian penalty. ${ }^{95}$ Instead, the stay of action accompanying the order will be continued. ${ }^{96}$ The order for ship's papers cannot, therefore, fall within section $17 .{ }^{97}$ There are two possible explanations: either the order for ship's papers in truth constitutes no part of the doctrine of utmost good faith at all, or, alternatively, it does form part of the doctrine but falls outside of section 17 , which may indeed be a possible interpretation of Chalmers' comment. If the latter is correct, it demonstrates again that section 17 embraces only part of a broader doctrine.

The most detailed judicial analysis of the post-formation duty of utmost good faith is to be found in The Star Sea. ${ }^{98}$ The insurers contended that, by virtue of the doctrine of utmost good faith, an assured that made a claim was under a duty to disclose all matters material to the insurers' treatment of that claim, that the standard of the duty mirrored that of the assured's pre-formation disclosure obligations and so was not confined to refraining from fraud, ${ }^{99}$ that this duty endured even beyond the instigation of legal proceedings in relation to the claim, and that this duty fell within section 17 so that breach afforded the insurers the right retrospectively

\footnotetext{
${ }^{91}$ Fargnoli $v$ GA Bonus plc [1997] CLC 653 (OH) 670; The Star Sea (n 14) [50]-[52]; Agapitos v Agnew (The Aegeon) (No 1) [2002] EWCA Civ 247, [2003] QB 556 [45(d)]; AXA General Insurance (n 83) [22]; The DC Merwestone (n 40) [8], [67], [119]. In Orakpo (n 79) 452, Sir Roger Parker considered that fraud in a claim could not attract a lesser sanction than innocent non-disclosure in the presentation of a risk, but Hoffmann LJ (451) adopted language indicative of repudiatory breach of contract. See also the text to 155 for the approach adopted under the Insurance Act 2015. It may be noted also that, in Banque Keyser Ullmann (n 58) 781, one ground on which a damages remedy was denied for breach by the insurer of its pre-formation duty of disclosure was that the duty fell within s 17, s 17 addressed remedies for breach, and in so doing it was to be considered as exhaustive. If that reasoning is correct (a better view might be that the reference to avoidance is directed at clarifying that a failure to observe the utmost good faith renders a contract voidable not void, contrary to several previous dicta, eg Carter (n 2) 1909; 1164), the availability of forfeiture of the claim as an independent remedy would be inconsistent with the making of a fraudulent claim constituting a failure to observe utmost good faith within $\mathrm{s} 17$.

${ }_{92}$ M Chalmers and D Owen, The Marine Insurance Act 1906, 2nd edn (London, Butterworth \& Co, 1913) 27.

${ }^{93}$ Graham Joint Stock Shipping Co Ltd v Motor Union Insurance Co Ltd [1922] 1 KB 563 (CA) 580; Leon (n 36) 579-80.

${ }^{94}$ Manifest Shipping Co Ltd v Uni-Polaris Insurance Co Ltd (The Star Sea) [1997] 1 Lloyd's Rep 360 (CA) 371.

${ }^{95}$ Also inconsistent with the amendment of rules of court in 1936 in response to the order having become (according to Greer LJ in Leon (n 36) 588) 'an unfair and unjust weapon in the hands of the insurer'. See The Sageorge (n 36) 641, 646 on the 1936 amendments, and generally on constraining inappropriate use of the order.

${ }^{96}$ London \& Provincial Marine \& General Insurance Co Ltd v Chambers (1900) 5 Com Cas 241.

${ }^{97}$ The Star Sea (n 14) [60].

${ }^{98}$ ibid.

${ }^{99}$ In oral argument, this contention was modified in favour of a test of unconscionable non-disclosure: ibid [106].
} 
to avoid the entire policy. The House of Lords rejected this argument on the basis that the duty attaching to the making of claims was confined to fraud and that once litigation commenced disclosure was governed by the rules of procedure.

In the course of a wide-ranging survey of the post-formation doctrine of utmost good faith, Lord Hobhouse addressed 'the problematic character of s 17'. ${ }^{100}$ He contrasted the prospective consequences in general contract law of a contract being discharged for a repudiatory breach with the retrospectivity of avoidance pursuant to section 17. In the post-formation context, such retrospectivity, with its attendant forfeiture of payments previously and properly received by the assured from the insurer, was 'effectively penal' and 'cannot be reconciled with principle.. ${ }^{101}$ He proposed the following approach:

A coherent scheme can be achieved by distinguishing a lack of good faith which is material to the making of the contract itself (or some variation of it) and a lack of good faith during the performance of the contract which may prejudice the other party or cause him loss or destroy the continuing contractual relationship. The former derives from requirements of the law which pre-exist the contract and are not created by it although they only become material because a contract has been entered into. The remedy is the right to elect to avoid the contract. The latter can derive from express or implied terms of the contract; it would be a contractual obligation arising from the contract and the remedies are the contractual remedies provided by the law of contract. ${ }^{102}$

Fundamentally, the doctrine of utmost good faith should not be transformed into an instrument of oppression affording an insurer inappropriate access to an extremely severe remedy. ${ }^{103}$ Had the parties intended the retrospective remedy of avoidance devised by general contract law to respond to problems in the formation of contracts to apply to a problem of performance, they could have so provided in the contract. In the absence of such an extension by the parties, Lord Hobhouse considered that any suggestion of such an extension as a matter of law should be carefully examined to determine whether it was compatible with 'the over-riding needs of justice. ${ }^{104}$ He continued as follows:

Where the application of the proposed principle would simply serve the interests of one party and do so in a disproportionate fashion, it is right to question whether the principle has been correctly formulated or is being correctly applied and it is right to question whether the codifying statute from which the right contended for is said to be drawn is being correctly construed. ${ }^{105}$

In the conclusion to his judgment, Lord Hobhouse returned to the theme of appropriate limits for the doctrine of utmost good faith:

[T] he courts should be on their guard against the use of the principle of good faith to achieve results which are only questionably capable of being reconciled with the mutual character of the obligation to observe good faith. ${ }^{106}$

In The DC Merwestone ${ }^{107}$ Lord Sumption, Lord Clarke and Lord Hughes all cited in full the first of these two latter passages and espoused the concern there articulated about proportionality.

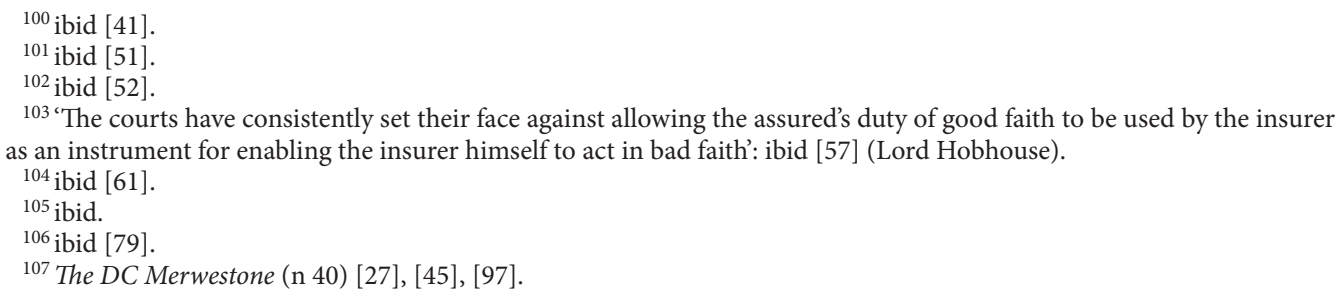


The question was whether the fraudulent claims rule with its forfeiture penalty should extend to instances of fraudulent statements made in support of a legitimate claim (known as 'fraudulent devices'). The Supreme Court held that such an extension would result in unduly harsh penalties. An assured that garnishes a genuine claim for no more than is genuinely due with a collateral untruth that does not affect the substance of the claim should not be assimilated to an assured that dishonestly seeks to deceive an insurer into making a payment to the assured to which the assured is not entitled. ${ }^{108}$

Proportionality was invoked in The DC Merwestone in relation to the scope of a common law rule within the doctrine of utmost good faith. On a similar basis, it has been suggested that, in rare circumstances, the doctrine of utmost good faith might deny an insurer a remedy to which it is in principle entitled. In Drake Insurance plc $v$ Provident Insurance plc, ${ }^{109}$ the assured's nondisclosure of a material circumstance did not induce the contract. Obiter, however, the Court of Appeal considered that the doctrine of utmost good faith could sustain a 'concept of proportionality implicit in fair dealing ${ }^{\text {'110 }}$ that would deny an insurer the remedy of avoidance where, at the time it purported to avoid, the insurer knew of circumstances that would have countered the materiality of the relevant circumstance if existing at the time of conclusion of the contract. ${ }^{111}$ Indeed, it was possible that an insurer that did not know of such circumstances but had notice of the possibility that they might exist should advise the assured that it was contemplating avoidance and afford the assured an opportunity to present any further information relevant to the question of materiality. ${ }^{112}$

The potential for the doctrine of utmost good faith to influence the construction of an insurance contract, or to facilitate the implication of a term into an insurance contract, has been more nebulous. It is clear that the express conferral of a contractual right on one party does not, of itself, attract a right of disclosure by the other of all information material to its exercise. The doctrine of utmost good faith does not, for example, intervene to embellish and strengthen an insurer's contractual cancellation right by implying a continuing post-formation obligation to disclose to the insurer all circumstances material to the possible exercise of that right. ${ }^{113}$ To require communication of each and every fresh material circumstance as it came to the knowledge of the assured throughout the duration of the risk 'would turn what is an indispensable shield for the Underwriter into an engine of oppression against the insured.'114 Any such obligation must be imposed expressly. ${ }^{115}$ Equally, a contractual discretion is not inherently subject to an implied fetter requiring its exercise to be consistent with the utmost good faith. An assured under a nonproportional reinsurance treaty enjoys an unfettered discretion in deciding whether or not to cede a particular risk. ${ }^{116}$

\footnotetext{
${ }^{108}$ For invocations of proportionality in The DC Merwestone (n 40) other than the quoted passage from The Star Sea (n 14) [61], see [47], [99], [103]. See also [109] (Lord Toulson): 'what is just and appropriate'.

${ }^{109}$ Drake Insurance plc $v$ Provident Insurance plc [2003] EWCA Civ 1834, [2004] QB 601.

${ }^{110}$ ibid [89] (Rix LJ).

111 ibid [91], [144]. Likewise, Brotherton v Aseguradora Colseguros SA (No 2) [2003] EWCA Civ 705, [2003] Lloyd's Rep IR 746 [34].

${ }^{112}$ This was accepted by Pill LJ (in Drake Insurance (n 109) [177]), but noted as requiring further consideration by Rix and Clarke LJJ (in Drake Insurance (n 109) [92], [145]).

${ }^{113}$ Commercial Union Assurance Co v Niger Co (1922) 13 Ll L Rep 75 (HL); New Hampshire Insurance Co v MGN Ltd [1997] LRLR 24 (CA) 60-61.

${ }^{114}$ Commercial Union Assurance (n 113) 82 (Lord Sumner).

${ }^{115}$ Commercial Union Assurance Co v Niger Co (1921) 6 Ll L Rep 235 (CA) 245.

${ }_{116}$ Aneco Reinsurance Underwriting Ltd v Johnson \& Higgins Ltd [2001] UKHL 51, [2002] 1 Lloyd's Rep 157, 192. For the underlying absence of any fetter as a matter of general contract law, see Glasgow Assurance Corp v Symondson \& Co (1911) 16 Com Cas 109 (KB) 122; Bonner v Cox [2005] EWCA Civ 1512, [2005] 2 Lloyd's Rep 152.
} 
Utmost good faith has, nevertheless, been invoked in relation to the implication of contractual terms. Where a term was implied in accordance with the normal principles of general contract law affording an insurer in the Lloyd's market access to placement and claims documents held in accordance with market practice by the broker, it was said that 'the insurance context, where good faith operates, supports that conclusion. ${ }^{117}$ Similarly, the standard contractual right of a liability insurer to conduct and control proceedings brought against the assured that could give rise to a claim is subject to an implied constraint. The insurer must not abuse the right but exercise it in good faith (not a reference to utmost good faith, but meaning for the purpose for which it is granted) and with proper regard to the interests of the assured, as the defendant in the proceedings, as well as its own, as contractually liable to indemnify the assured in respect of such liability as established in the proceedings. ${ }^{118}$ This restriction again appears to be implicit in the grant of the power of control, and sustainable as a matter of general contract law, ${ }^{119}$ but it has also been associated with the doctrine of utmost good faith. ${ }^{120}$

A supporting role where an implication arises as a matter of general contract law amounts, however, to nothing. The key question is whether utmost good faith could ever support the implication of a term in circumstances where general contract law would deny any implication.

In Gan Insurance Co Ltd v Tai Ping Insurance Co Ltd (Nos 2 \& 3), ${ }^{121}$ a claims cooperation clause in a reinsurance contract forbade any settlement, compromise or admission of liability without the reinsurers' prior consent. Mance LJ, with whose judgment Latham LJ agreed, held that the reinsurers' right to withhold consent was fettered by the context and purpose of the right and that any withholding of consent 'should take place in good faith after consideration of and on the basis of the facts giving rise to the particular claim and not with reference to considerations wholly extraneous to the subject-matter of the particular reinsurance. ${ }^{122}$ Mance LJ stated, however, that this implication derived not from any principles special to insurance law, but rather 'from the nature and purpose of the relevant contractual provisions. ${ }^{123}$ Subsequently, nevertheless, in Eagle Star Insurance Co Ltd v Cresswell, ${ }^{124}$ Rix LJ, noting that the Court of Appeal had not been unanimous in Gan $v$ Tai Ping, commented of the majority's implied fetter on the reinsurers' right to withhold consent that 'this protection may not depend only on a term to be implied "for business efficacy", but may be inherent as a matter of law in the very essence of the reinsurers' mutual obligation of good faith.' ${ }^{125}$

It remains unclear whether and, if so, to what extent the doctrine of utmost good faith is in truth relevant to questions of construction of insurance contracts and implication of terms into

\footnotetext{
${ }^{117}$ Goshawk Dedicated Ltd v Tyser \& Co Ltd [2006] EWCA Civ 54, [2006] 1 Lloyd’s Rep 566 [53] (Rix LJ).

${ }^{118}$ Groom v Croker [1939] 1 KB 194 (CA).

${ }^{119}$ Zurich Australian Insurance Ltd v Metals \& Minerals Insurance Pte Ltd [2007] WASC 62, (2007) 209 FLR 247 [264].

${ }^{120}$ Cox v Bankside Members Agency Ltd [1995] CLC 671 (CA) 693 (Saville LJ). Sir Thomas Bingham MR rejected any suggestion that breach by the insurer of the constraint 'gives the assured no right other than rescission' (ibid 680), but it is unclear whether this is based upon the implied fetter not deriving from the doctrine of utmost good faith at all or constitutes an affirmation of remedial flexibility in the post-formation doctrine of utmost good faith. It is not credible that rescission is available on any analysis.

${ }^{121}$ Gan Insurance Co Ltd v Tai Ping Insurance Co Ltd (Nos 2 \& 3) [2001] EWCA Civ 1047, [2001] Lloyd’s Rep IR 667.

122 ibid [67] (Mance LJ, Latham LJ concurring, Sir Christopher Staughton dissenting).

123 ibid [68].

${ }^{124}$ Eagle Star Insurance Co Ltd v Cresswell [2004] EWCA Civ 602, [2004] 1 CLC 926 [54].

${ }^{125}$ Likewise, Phoenix General Insurance Co of Greece SA v Halvanon Insurance Co Ltd [1985] 2 Lloyd's Rep 599 (Com Ct) 613-14 (Hobhouse J), accepting as a matter of common law an implied term as to maintenance of and access to records 'which would probably be imported anyway by the duty of good faith. However, it is the contractual analysis that has recently been reiterated: Equitas Insurance Ltd v Municipal Mutual Insurance Ltd [2019] EWCA Civ 718, [2019] Lloyd's Rep IR 359 [109] (implied term that reinsurance claims relating to mesothelioma must be presented in a manner that is not arbitrary, irrational or capricious).
} 
insurance contracts. There appears to be no example of the doctrine having changed the result achieved by the normal principles of general contract law.

\section{Conclusions in Relation to Section 17}

In the light of the preceding discussion, some simple propositions emerge about the architecture of utmost good faith in its second age and the role of section 17 of the Marine Insurance Act 1906. It is worth reiterating that the debate about the role of section 17 is driven by concerns about remedy. The section is unequivocal: a failure by one party to observe the utmost good faith to which the section speaks, namely the utmost good faith on which an insurance contract is 'based', entitles the other party to avoid the contract. Conceptually, such retrospective avoidance responds in the logic of general contract law to the vitiation of the consent that lies at the heart of a contract's formation. It is not a recognised response to issues that arise during the lifetime of a contract. That is not to assert that it would be technically impossible for avoidance to constitute the law's response to a particularly serious issue under a particular type of contract, such as the making of a fraudulent claim under an insurance contract, were it considered appropriate. However, recognising the potentially excessive and arbitrary consequences of retrospective avoidance, the courts have indicated that the remedy would not be an appropriate response even to egregious dishonesty in the operation of a concluded policy.

The ineluctable conclusion is that section 17 and its remedy of avoidance must be confined to situations of vitiated consent in the formation of insurance contracts. Logically, there are two ways to achieve this: either all other situations that are candidates for the application of the doctrine of utmost good faith must be analysed as not in fact attracting the application of that doctrine, or the doctrine must be recognised as broader than section 17, with different, and appropriate, remedies attaching to aspects of the doctrine falling outside section 17. 'Held covered' clauses support the second option. As discussed above, ${ }^{126}$ since they involve the making of an underwriting decision, they clearly attract the doctrine of utmost good faith, but, since they do not trigger the formation of a new contract, they do not fit within the pre-formation doctrine, and, since their purpose is to trigger an extension to cover, retrospective avoidance of the entire policy in response to a potentially innocent failure to disclose a circumstance material to the extension would be grossly disproportionate. Held covered clauses should therefore be accepted as falling within the postformation doctrine of utmost good faith but outside of section 17, so that the remedial response to non-disclosure or untruth of statement in relation to circumstances material to the underwriting decision to be made under the held covered clause can be confined to loss of the extension of cover under the clause.

The fraudulent claims jurisdiction and the order for ship's papers submit to a similar analysis. In neither case does the doctrine of utmost good faith apply as a matter of irrefutable logic; the law should have been capable of generating such developments without any assistance from a broader doctrine. In each case, however, the case law is clear that the doctrine was invoked as a basis for the legal response to the relevant problem, but not so as to constrain that response within a remedial straitjacket. The sensible approach is, therefore, again to acknowledge the fraudulent claims jurisdiction and the order for ship's papers as aspects of the doctrine of utmost good faith but as falling outside of section 17 , so that there is no conflict between the remedies acknowledged by the courts for making a fraudulent claim or for non-compliance with an order for ship's papers and the remedy of avoidance as granted by section 17 .

\footnotetext{
${ }^{126}$ See text to nn $73-78$.
} 
The same is true of other possible instances of utmost good faith. If the doctrine influences the construction of a contractual or statutory provision, or provides the (or a) basis for implying a term into an insurance contract, acting contrary to the relevant provision so construed or implied may perhaps be characterised as failing to observe the utmost good faith. It does not, however, follow that avoidance is an appropriate, or even a logically possible, remedial response. If the Court of Appeal in Drake Insurance was correct as regards the suggested restriction on the right of avoidance, ${ }^{127}$ the consequence must be that in appropriate circumstances the insurer does not have the right to avoid. And there is no justification for insurance contract law departing from general contract law in its response to breach of a contract term. ${ }^{128}$

Finally, recognising that the doctrine of utmost good faith extends beyond section 17 accommodates the independent duties of disclosure and truth of statements in relation to material circumstances owed by placing brokers, given that section 17 is concerned with the observing of utmost good faith by the parties to the contract.

The net result is that section 17 articulates only part of the second age doctrine of utmost good faith, namely that which applies to the parties to a putative insurance contract at the stage of contract negotiation. It is in this sense that insurance contracts are 'based' on the utmost good faith to which the section speaks. Section 18 is correctly regarded as elaborating one aspect of the section 17 doctrine. The same is true of section 20 to the extent that it applies to the assured. Section 17 also supports aspects of pre-formation utmost good faith required of the parties that are not addressed in subsequent sections of the 1906 Act, as discussed above. ${ }^{129}$

This analysis is supported by the seminal judgment of Lord Hobhouse in The Star Sea, a central theme of which is an acknowledgement of the remedial problems attached to section 17 and of the need to ensure that various manifestations of utmost good faith are enforced by appropriate remedies. This approach is reinforced by the decision of the Supreme Court in The DC Merwestone, ${ }^{130}$ in which the question of whether a fraudulent device fell within the fraudulent claims jurisdiction was determined by considering whether the remedies attaching to a fraudulent claim were appropriate for a fraudulent device.

Contrast a second, short judgment in The Star Sea, that of Lord Clyde. He recognised that post-formation duties arising from the doctrine of utmost good faith would vary with respect to their content from the pre-formation duties and from one another. He refused, however, to overcome any argument that section 17 mandated a uniform standard and scope for all postformation duties by confining section 17 to pre-formation duties. That approach he declared with no elaboration to be 'past praying for.' ${ }^{131}$ Instead, the requisite flexibility was to be found in the phrase 'utmost good faith', which, in particular, extended to innocent non-disclosure and misrepresentation at the pre-formation stage but was confined to fraud in the context of claims. Lord Clyde wholly failed, however, to engage with the question of remedy, which is fundamental to the scope of section $17 .^{132}$

\footnotetext{
${ }^{127}$ See text to $\mathrm{n} 109$.

${ }^{128}$ Goshawk Dedicated (n 117) [53] (Rix LJ): the issue is not that certain conduct constitutes a failure to observe the utmost good faith, but rather that 'the duty informs the content of the contractual obligation'.

${ }^{129}$ See text to $\mathrm{nn} 68-72$.

${ }^{130}$ Discussed in the text to $\mathrm{n} 107$.

${ }^{131}$ The Star Sea (n 14) [6], quoted in The Mercandian Continent (n 65) [34].

${ }^{132}$ The other reasoned judgment in The Star Sea (n 14), that of Lord Scott, contains elements of confusion. He was adamant (at [81]) that s 17 could not be confined to pre-formation aspects of utmost good faith, but simply because the doctrine was established as having a post-formation dimension (relying in that respect, inter alia, on The Litsion Pride (n 61), which was overruled in The Star Sea as advancing an illegitimate extension of the doctrine: ibid [71]). He therefore assumed that all aspects of the doctrine of utmost good faith fell within $\mathrm{s} 17$, which he carried through to the question of remedy, asserting that a fraudulent claim triggered a right of avoidance (although in another passage (at [110]) he
} 
With respect, this remedial omission is fatal to the peremptory dismissal of the approach to section 17 advanced in this chapter and supported by the extended and compelling reasoning of Lord Hobhouse. For the doctrine of utmost good faith to apply in appropriately tailored ways to selected post-formation aspects of insurance contracts, flexibility is imperative not only with respect to the duties imposed, but also with respect to the remedies for non-compliance. Section 17 denies the requisite flexibility of remedy. It is therefore imperative, in the framework of the statutory provisions applicable to utmost good faith in its second age, to recognise the post-formation dimension of the doctrine of utmost good faith as independent of section $17 .{ }^{133}$

\section{The Third Age: The Insurance Act 2015}

The third age of utmost good faith commenced with the entry into force of the Insurance Act 2015 on 12 August 2016. The new utmost good faith regime introduced by the 2015 Act applies to insurance contracts concluded on or after that date and to variations concluded on or after that date to contracts concluded before it. ${ }^{134}$ Insurance contracts and variations concluded before that date remain subject to the second age rules.

The 2015 Act, which enacts proposals of the English and Scottish Law Commissions, ${ }^{135}$ implements major structural and substantive reforms to the doctrine of utmost good faith. The Act introduces the concept of a 'duty of fair presentation of the risk' owed by the assured to the insurer whenever negotiating a new insurance contract or variation to an existing insurance contract. ${ }^{136}$ This duty encompasses obligations of disclosure and truth of statement. No independent duty of the placing broker is recognised, but the knowledge of any individual, whether or not employed by the assured, who participates on behalf of the assured in the process of procuring the assured's insurance is attributed to the assured. ${ }^{137}$ And the duty to make a fair presentation of the risk is clearly non-delegable, so that any failure by a placing broker to effect the disclosure or meet the truth of statement required to comply with the duty is a failure of the assured.

An insurer seeking a remedy for an alleged breach of the duty of fair presentation of the risk must always prove that the non-disclosure or misrepresentation satisfies uniform tests for materiality and inducement, ${ }^{138}$ even if the breach is fraudulent. To that extent, the Act is,

considered debatable whether a fraudulent claim constituted a breach of s 17 entitling avoidance), but not considering how s 17 would work remedially in the context of held covered clauses, to which he also referred. Lord Scott failed, therefore, to distinguish between the scope of s 17 and the scope of the doctrine of utmost good faith, but nevertheless also agreed with the reasoning of Lord Hobhouse. Unhelpfully, Lord Hoffmann agreed with both Lord Hobhouse and Lord Scott, as did Lord Steyn, who agreed with Lord Clyde as well.

${ }^{133}$ Remedial inflexibility will, moreover, render utmost good faith an unappealing instrument for resolving diverse problematic issues. In Equitas Insurance (n 125) [104], post-formation utmost good faith was rejected by Males LJ as a basis for an implied requirement as to the allocation of losses between reinsurance contracts since it 'gives rise to a remedy of avoidance of the contract rather than a constraint on the exercise of prima facie contractual rights'

${ }^{134}$ Insurance Act 2015, s 22(1).

${ }^{135}$ Law Com No 353 (n 90).

${ }^{136}$ Insurance Act 2015, s 3 .

${ }_{137}$ ibid ss 4(3)(b), (8)(b).

${ }^{138}$ The latter under the rubric of 'qualifying breach': Insurance Act 2015, s 8. This requires proof that the breach of duty in some way altered the underwriter's decision, although technically not proof of specifically in what respect that decision was altered (although in practice it may be difficult to convince a court of the former without proof of the latter). Proof of the precise alteration is then required in respect of non-fraudulent breaches in order to apply the statutory scheme of proportionate remedies. 
surprisingly, more indulgent to fraud than the earlier ages of utmost good faith which follow general contract law. ${ }^{139}$

An insurer that establishes that the duty of fair presentation of the risk has been broken by a material non-disclosure or a material misrepresentation, and that the breach induced the insurer to conclude the contract at all, or on the terms agreed, is entitled to the appropriate remedy from a scheme of proportionate remedies. Within that scheme, avoidance is confined to cases of fraud and cases where, but for the breach of duty, the insurer would not have entered into the contract at all. Otherwise, where the insurer would have concluded the contract but on different terms, the insurer's remedy lies in retrospective rectification of the policy to the terms that would have been agreed, and where the insurer would have concluded the contract but charged a higher premium, the remedy consists of a proportionate reduction in the measure of indemnity. ${ }^{140}$

Having established the duty of fair presentation of the risk, the 2015 Act then abolishes any rule of law permitting a party to a contract of insurance to avoid the contract on the ground that the utmost good faith has not been observed by the other party.' ${ }^{141}$

In consequence of these reforms, the 2015 Act then repeals sections 18-20 of the Marine Insurance Act 1906, ${ }^{142}$ and amends section 17 of the 1906 Act so that it provides simply that 'A contract of marine insurance is a contract based upon the utmost good faith.' ${ }^{143}$ The explicit reference to the mutuality of the doctrine and the statement of the right to avoid in the event of failure to observe the utmost good faith are removed.

As discussed above, the structural problems afflicting the doctrine of utmost good faith in its second age flowed from the attachment of the remedy of avoidance to any failure to comply with the injunction of section 17. This is addressed, first, by amending section 17 to leave the provision silent as to the consequences of a failure to observe the utmost good faith, and, secondly, by the abolition of avoidance as a remedy for any failure to observe the utmost good faith. Avoidance nevertheless remains the remedy in certain instances of breach of the duty of fair presentation of the risk. A clear structural point follows. Since the duty of fair presentation of the risk can attract a remedy that a failure to observe the utmost good faith in its third age can never attract, it follows that the duty of fair presentation of the risk does not form part of the third age doctrine of utmost good faith. In its third age, therefore, the doctrine of utmost good faith is shorn of the pre-formation disclosure obligations that were primarily responsible for the doctrine's recognition and which constituted its most significant manifestation during its first two ages.

The duty of fair presentation of the risk attaches not only to the formation of new insurance contracts, but also to the variation of existing insurance contracts, with the potential for avoidance reflecting the conclusion of a separate contract involved in a variation, ${ }^{144}$ as discussed

\footnotetext{
${ }^{139}$ On the stricter approach to fraud and materiality, see above, text to nn 69-70. With respect to inducement, in cases of fraud 'the court does not allow an examination into the relative importance of contributory causes', so there is no need to show any particular level of impact of the fraud on the mind of the deceived party: Barton $v$ Armstrong [1976] AC 104 (PC) 118 (Lord Cross). It suffices that the fraudulent statement (or the matter in relation to which there is fraudulent non-disclosure) was 'actively present to' the insurer's mind and it is irrelevant that the insurer was also actuated by other contributing inducements: Edgington v Fitzmaurice (1885) 29 Ch D 459 (CA) 483 (Bowen LJ). See also BV Nederlandse Industrie van Eiprodukten $v$ Rembrandt Enterprises Inc [2019] EWCA Civ 596, [2019] 1 Lloyd's Rep 491. This appears to have been overlooked by the Law Commissions, which erroneously considered the test for a qualifying breach to replicate the existing law on inducement: Law Com No 353 (n 90) para 11.11.

${ }^{140}$ Insurance Act 2015, s 8, sch 1, pt 1.

${ }^{141}$ Insurance Act 2015, s 14(1).

142 ibid s 21(2). Nor is there any argument that an underlying common law rule might revive in the light of repeal of the statutory provisions: $\mathrm{s} 22(3)$

143 ibid s 14(3)(a).

${ }^{144}$ Insurance Act 2015, s 2(2), sch 1, pt 2.
} 
previously. ${ }^{145}$ The duty does not, however, encompass all aspects of the second age pre-formation doctrine. Since no other ground for avoidance of the policy on the basis of a failure to observe the utmost good faith survives into the third age, it follows that aspects of the second age preformation doctrine falling outside the duty of fair presentation of the risk but triggering a right to avoid the policy under the second age section 17 have been abolished, retained within the doctrine of utmost good faith but with a different remedy, or relocated to the province of a different doctrine.

Specifically, first, the reciprocal duties of disclosure and truth of statement owed by the insurer to the assured have not survived. The view of the Law Commissions was that matters such as the selling of worthless insurance are better addressed through industry regulation. ${ }^{146}$ Secondly, confinement of the duty of fair presentation of the risk to material circumstances eliminates any scope for pre-formation utmost good faith to attach as a matter of law to non-material circumstances about which the particular underwriter happens to be concerned. The Law Commissions, indeed, were 'doubtful' as a matter of principle whether non-disclosure or misrepresentation of a non-material circumstance 'should attract any remedy at all, ${ }^{147}$ and certainly not avoidance. Under the 2015 Act, therefore, any such matters would have to be made the subject of express contractual provision, either by widening the definition of materiality by using the contractingout facility within the $\mathrm{Act}^{148}$ or by including an express stipulation. Thirdly, the Law Commissions considered that the possibility of realisation by one party of a mistake being made by the other should be left to general contract law. ${ }^{149}$

In contrast to this contraction of utmost good faith, the liberation of section 17 from remedial constraints allows the general doctrine of utmost good faith doctrine as articulated by the amended section to provide a foundation for other duties arising from utmost good faith, namely the post-formation duties. These can be fashioned so that they respond in the most appropriate manner to the relevant issue, adopting, in accordance with the analysis proposed by Lord Hobhouse in The Star Sea, ${ }^{150}$ the apparatus and remedies of general contract law, albeit with bespoke modifications where appropriate.

Within the amended section 17 fall, therefore, the disclosure and truth of statement obligations that attach to the triggering of held covered clauses, which, as discussed above, ${ }^{151}$ involve the exercise of pre-existing rights rather than a distinct contract to vary. While the duties are directly analogous to those that arise in the pre-formation context, they apply by means of implication into the held covered clause, with non-compliance constituting the non-fulfilment of a condition precedent to the clause's operation, a consequence that does not involve avoidance. ${ }^{152}$

A second example of third age section 17 utmost good faith is the fraudulent claims jurisdiction. The 2015 Act sets the remedial side of the jurisdiction on a statutory basis, ${ }^{153}$ in order to provide clarity to an area of the law that had seen significant recent litigation and to 'remove the

\footnotetext{
${ }^{145}$ Above, text following $\mathrm{n} 60$.

${ }^{146}$ Law Com No 353 (n 90) para 30.34.

147 ibid para 30.30 .

${ }^{148}$ See Insurance Act 2015, ss 16-17.

${ }^{149}$ Law Com No 353 ( $\mathrm{n} 90$ ) para 30.30, also noting that the failure to inform the insurer of the mistake might constitute a breach of the duty of fair presentation. The examples cited in the case law (above, text to $\mathrm{n} 72$ ) would not, however, constitute mistakes as to contract terms within the rule in Smith (n 1).

${ }^{150}$ Above, text to $\mathrm{n} 102$.

${ }^{151}$ Above, text to nn 73-77.

${ }^{152}$ The Law Commissions considered that held-covered clauses would be treated as variations for the purpose of the duty of fair presentation of the risk: Law Com No 353 (n 90) para 30.41. However, no analysis is provided to support this expectation and, as discussed above, an exercise of existing rights is not a variation.

${ }^{153}$ Insurance Act 2015, s 12.
} 
problems created by section 17 of the Marine Insurance Act 1906. ${ }^{154}$ For the most part, the 2015 Act codifies the outcome of that case law. Consistently with a breach of contract approach to post-formation utmost good faith, however, the 2015 Act resolves the undecided question of the impact of a fraudulent claim beyond the claim on the contract as a whole in favour of regarding a fraudulent claim as a repudiatory breach triggering, at the insurer's election, a prospective discharge, albeit with bespoke consequences in that an insurer's election to treat the contract as discharged takes effect as from the time of the fraud, not the time of the insurer's acceptance of the breach. ${ }^{155}$ Questions regarding the scope of the jurisdiction remain, however, for the common law and should be analysed through the lens of utmost good faith. ${ }^{156}$

As discussed in previous sections, the doctrine of utmost good faith is not necessarily confined to imposing duties of disclosure and honesty in various contexts. The Law Commissions envisaged the retained doctrine functioning as a 'general interpretative principle, ${ }^{157}$ and suggested three ways in which it might serve a useful purpose. ${ }^{158}$

The first is to provide assistance in interpreting the duty of fair presentation of the risk:

Both parties are expected to act in good faith in exchanging information. For example, if a court were to find that an insured had intentionally disclosed only the bare minimum of information, hoping that the insurer would fail to make further enquiries to reveal the full picture, the insured would not have acted in good faith and would therefore be in breach of the duty of fair presentation. ${ }^{159}$

The duty of fair presentation of the risk introduces the idea that the assured might fail to disclose all material circumstances, but might, nevertheless, make it clear to a prudent insurer that further material information was available if requested. ${ }^{160}$ Disclosure of a bare minimum with no signalling that more information is available will by definition not satisfy the duty. The point being made by the Law Commissions seems to be that any finding of deliberate intention to produce the result that the insurer does not learn of certain material information will militate strongly against, if not automatically preclude, a finding of partial but adequate disclosure. Absent any such intention, however, it is unclear whether the principle of utmost good faith will be of any assistance in partial disclosure cases. While it may be argued that utmost good faith should tip the balance against an assured that fails to make full up-front disclosure, equally it may be argued to the contrary that utmost good faith now requires an insurer to be astute to the possibility of the need for supplementary enquiries. Whatever the merits of the specific example offered by the Law Commissions, however, it was recognised even in the first age of the doctrine that the interpretation of legislation relating to insurance contracts might be influenced by the fundamental idea that such contracts are based on the utmost good faith. ${ }^{161}$

The second role for utmost good faith envisaged by the Law Commissions is:

To inform the need to imply contractual terms into the policy under the traditional 'business efficacy' test. Good faith provides a background when considering whether it is necessary to imply a particular term. ${ }^{162}$

\footnotetext{
${ }^{154}$ Law Com No 353 (n 90) para 21.1.

${ }^{155}$ Indeed, this is a consequence of abolishing avoidance as a remedy for failure to observe the utmost good faith (Law Com No 353 (n 90) para 22.3), showing, in turn, that the Law Commissions envisage the fraudulent claims jurisdiction as continuing to be part of the doctrine of utmost good faith.

${ }^{156}$ Perhaps influencing, for example, the tolerance to be allowed for deliberate exaggeration in the making of a claim in order to afford room for negotiation yet still recover the true loss.

${ }^{157}$ Law Com No 353 (n 90) para 30.5.

158 ibid para 30.23 .

${ }^{159}$ ibid.

${ }^{160}$ Insurance Act 2015, s 3(4)(b).

${ }^{161}$ See text to $\mathrm{n} 22$.

${ }^{162}$ Law Com No 353 (n 90) para 30.23.
} 
That an insurance contract is based on the utmost good faith should, accordingly, favour the implication of duties of cooperation and transparency. As already noted, reference has been made to utmost good faith in the context of implying duties regarding the provision of access to records and other documentation. ${ }^{163}$ Although the courts would have upheld the same implications even in the absence of the doctrine of utmost good faith, the presence of that doctrine may support such a conclusion and perhaps ease the way towards gaining acceptance in the judicial mind. The Law Commissions, however, go further and suggest that the retained principle is capable of permitting the implication of terms in insurance contracts that would not pass the general contract law test for implication: 'Identifying good faith as a component of business efficacy recognises the unique nature of insurance contracts, and allows the courts to imply terms which would not be considered necessary outside the field of insurance. ${ }^{164}$ Equally, one might add that when faced with an issue of construction, the nature of the transaction as of utmost good faith may assist, or at least be taken into account, in the search for the meaning to be ascribed to express policy wording. Such an idea again can be traced back to the first age of the doctrine. ${ }^{165}$

The final role for utmost good faith envisaged by the Law Commissions is to provide a juridical basis for the exercise of judicial flexibility. They explain as follows:

It is possible that the principle of a mutual duty of good faith could provide a solution to an especially hard case or emergent difficulty. Although we think such cases would be extremely rare, it is possible that the courts could develop the concept to prevent an insurer from relying on a right to deny a claim where it would be manifestly unfair to do so. ${ }^{166}$

This clearly references the suggestion in Drake Insurance ${ }^{167}$ that avoidance may be denied where post-formation but pre-avoidance evidence reveals that the materiality of a non-disclosed or misrepresented circumstance was in fact based on inaccurate or incomplete information and that accurate or complete information, if available at the time of conclusion of the contract, would have denied materiality.

To what extent any of these suggestions bears fruit remains to be seen, but the amending of section 17 makes it easier for the statutory pronouncement of utmost good faith as the basis of insurance contracts to sustain and encompass any such developments free from any inappropriate remedial repercussions. ${ }^{168}$

\section{Conclusion}

The evolution of utmost good faith can be divided into three ages. The first age corresponds to the period before 1 January 1907, the date when the Marine Insurance Act 1906 entered into force, during which the idea emerged of insurance contracts commanding an enhanced standard of good faith to which the label 'utmost good faith' was increasingly attached. The second age spans the subsequent period of nearly 110 years, during which utmost good faith was the subject

\footnotetext{
${ }^{163}$ See text to $n 117$.

${ }^{164}$ Law Com No 353 (n 90) para 30.60.

${ }^{165}$ See text to nn 50-51.

${ }^{166}$ Law Com No 353 (n 90) para 30.23.

${ }^{167}$ See text to $n 109$.

${ }^{168}$ For a sceptical view, see M Hemsworth, 'The Fate of "Good Faith" in Insurance Contracts' [2018] Lloyd's Maritime and Commercial Law Quarterly 143; for a view that s 17 could prove more productive, not least by analogy with developments in Australia, see B Soyer and A Tettenborn, 'Mapping (Utmost) Good Faith in Insurance Law - Future Conditional?' (2016) 132 Law Quarterly Review 618.
} 
of sections 17-20 of the 1906 Act. Considerable problems of structure and substance arose by reason of the drafting of section 17 , and specifically the attaching of the remedy of avoidance of the contract to any and every failure to observe the utmost good faith as contemplated by that section. The solution, as argued in this chapter, is to recognise that section 17 encompasses only part of the second age doctrine, namely the reciprocal pre-formation duties of disclosure and truth of statement owed by the assured and insurer to each other. The third, and current, age sees the doctrine lose its signature pre-formation duties in favour of the new duty of fair presentation of the risk, but also the liberation of section 17 through the removal of any reference to a remedy.

Throughout its history, the doctrine of utmost good faith has not dictated the duties that have arisen under its auspices. Instead, the phrase was applied to insurance contracts as a pithy means of encapsulating the attachment to such contracts of distinctive legal rules and attitudes requiring, in comparison with contracts generally, an enhanced level of openness, candour and fair dealing.

Looking to the future, the Insurance Act 2015 robs the doctrine of utmost good faith of much of its glamour. Gone are the days of the doctrine's functioning, principally by reason of the extensive demands of pre-formation disclosure and unyielding remedy of avoidance in the event of non-compliance, as probably the key substantive doctrine of insurance contract law. Instead, it has been moved from centre stage to the wings, relegated to providing theoretical underpinnings for post-formation duties of disclosure and honesty, potentially oiling the wheels of implication of contract terms and of both contractual and statutory interpretation, and possibly restraining rights in exceptional cases where their exercise would be grossly unreasonable. It can, however, rest content: its reformed progeny, the duty of fair presentation of the risk, will assume the central role and continue to reflect, through its historical origins, ethos and strictures, albeit not its technical affiliation, the fact that insurance contracts remain based on the utmost good faith. 